Tempo Social; Rev. Sociol. USP, S. Paulo, 10(1): 185-214, maio de 1998.

\title{
A competição profissional no mundo do Direito
}

\author{
MARIA DA GLORIA BONELLI
}

RESUMO: Este artigo focaliza o mundo profissional do Direito numa comarca de médio porte do interior do Estado de São Paulo, analisando a dinâmica deste campo centrada na competição profissional entre juízes, advogados, funcionários de cartório, promotores de justiça e delegados de polícia. O mundo do Direito engloba, além dessas competições interprofissionais, as competições intraprofissionais que são estudadas detalhadamente aqui para o caso dos juízes, dos delegados de polícia e dos funcionários de cartório. Esta concepção procura relacionar os lugares ocupados por eles no sistema das profissões como fatores condicionantes das suas interações, estabelecendo as possibilidades e fornecendo os recursos para as mudanças buscadas através das disputas profissionais. A análise das tensões entre o Judiciário e o Legislativo delimitam o pertencimento dos profissionais ao mundo do Direito, configurando-o como um grupo com uma dimensão comum, em conflito com as posições tomadas pelos legisladores.

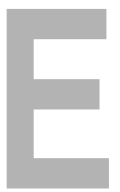

ste trabalho focaliza o campo profissional que circunda a atividade da justiça numa comarca do interior do Estado de São Paulo. Ele é parte de uma pesquisa mais ampla sobre as relações profissionais na área do Direito. Nela, focalizamos as formas como as interdependências dessas diversas especializações no mundo do trabalho judicial condicionam seus conflitos e disputas.

A concepção que norteia a pesquisa identifica as profissões que atuam nesta área como constituindo um campo movido pela interação e pela competição entre os diversos profissionais que lidam com esta temática como seu trabalho cotidiano. No caso da região investigada, eles são os juízes, os
UNITERMOS: profissões, direito, comarca paulista.
Professora do Departamento de Ciências Sociais da UFSCar 
1 Para uma revisão da bibliografia da Sociologia das Profissões que discuta e aprofunde tal concepção, cf. Bonelli \& Aguiar \& Donatoni (1994). promotores de justiça, os delegados de polícia, os advogados e os funcionários de cartório judicial.

A abordagem adotada aqui identifica, na base da relação mantida por estes profissionais, uma interação competitiva dada pela posição que eles ocupam no universo das profissões. A própria estrutura que estas profissões formam ao se relacionarem umas com as outras gera a interdependência das diferentes ocupações e as diversas perspectivas que elas adotam sobre a justiça e seu funcionamento.

Os lugares de onde cada uma dessas profissões e seus segmentos internos se relacionam no universo profissional condicionam as interações mantidas entre elas ao mesmo tempo que geram possibilidades de ação em busca de melhores posições dentro do sistema profissional. Tanto os constrangimentos quanto os incentivos que esta estrutura engendra se materializam nas tensões, nos conflitos e na dinâmica do campo da justiça e pode ser captada na forma como ela se concretiza na região estudada, facilitando a compreensão de sua lógica.

A competição profissional é enfocada aqui sob dois prismas complementares: as disputas intraprofissionais e as interprofissionais. A primeira delas se refere à competição entre os pares profissionais e está relacionada à própria estratificação de cada ocupação. A segunda examina as tensões decorrentes das disputas entre profissões distintas que atuam em áreas próximas e procuram imprimir sua forma de lidar com a questão comum a elas. Ambas as formas de competição são condicionadas pela posição que a profissão e o profissional ocupam neste sistema ${ }^{1}$.

As profissões que serão estudadas aqui estão organizadas de uma maneira independente umas das outras com carreiras próprias. A concepção de que elas formam um sistema baseia-se no desenvolvimento prático da atividade profissional, nas áreas de fronteira que possuem e no objeto que tem em comum que é a justiça, embora lidem com ela sob perspectivas diferentes. Essas relações originadas em decorrência do trabalho neste campo configuram o que chamaremos de 'mundo do Direito'.

O objetivo do trabalho aqui desenvolvido é vincular o enfoque exposto acima com a lógica que movimenta o 'mundo do Direito', numa comarca de médio porte, aplicando o modelo analítico a uma realidade empírica. Para tanto, analisaremos as relações profissionais, as redes de conexões entre esses indivíduos, as suas características morfológicas, como a origem social e a trajetória profissional, além dos diferentes formatos organizacionais de cada profissão e das suas respectivas estruturas internas, procurando demonstrar como tal campo jurídico construído teoricamente ganha existência real na prática do exercício profissional. Neste sentido, o trabalho priorizará o uso dos dados coligidos para dar maior transparência à forma como esse modelo de análise auxilia a compreensão do objeto de estudo.

A comarca investigada, que será denominada de Branca, é composta de dois municípios e dois distritos, com uma população total em torno dos 
BONELLI, Maria da Gloria. A competição profissional no mundo do Direito. Tempo Social; Rev. Sociol. USP, S. Paulo, 10(1): 185-214, maio de 1998.

177 mil habitantes em 1991. A comarca Branca possui quatro varas cíveis, duas varas criminais e um juizado de pequenas causas. Como se trata de uma cidade de médio porte, a comarca é de terceira entrância. O Poder Judiciário possui também comarcas de primeira entrância, de segunda entrância e de entrância especial, de acordo com o tamanho da cidade. Elas vinculam-se à primeira instância do Poder Judiciário. São nas varas dessas entrâncias que um processo começa a caminhar na roda que movimenta a justiça.

A segunda instância configura-se como uma possibilidade de recurso na estrutura do Poder Judiciário, onde atuam os desembargadores. No Ministério Público, os profissionais vinculados ao segundo grau são procuradores de justiça e os de primeiro grau são promotores de justiça².

O ingresso em ambas as carreiras começa pela posição de juiz substituto ou promotor substituto. Esta denominação é originária do fato do recém-concursado ser designado para trabalhar em uma circunscrição judicial (comarcas maiores que englobam administrativamente as menores) que já possui promotores ou juízes vitaliciados. A progressão na carreira para vitaliciado se dá num prazo de dois anos, mas como há falta de profissionais, o substituto acaba sendo promovido para a primeira entrância antes de se tornar vitalício. Conforme vão surgindo vagas eles vão galgando novas posições nas comarcas maiores, desde que se inscrevam para tal.

Cada uma das varas que compõe a comarca Branca conta com um juiz e um cartório judicial. São, portanto, 6 juízes, sendo 4 cíveis e 2 criminais. O Juizado Especial de Pequenas Causas é acumulado pelos juízes da vara cível, sendo que a direção é exercida por um deles de forma fixa e o trabalho decisório sobre os processos é feito num sistema de rodízio, assumindo a cada seis meses um dos juízes dessas varas. No Ministério Público, a distribuição dos promotores pelas áreas se inverte. Há 6 promotores, sendo 2 ligados à esfera cível e quatro à esfera criminal.

Já as delegacias de polícia da região possuem uma outra estrutura que apresenta pontos de conexão com a do Judiciário e do Ministério Público locais. Elas são vinculadas ao Poder Executivo, que é responsável pela atividade policial militar e civil. Os delegados de polícia vinculam-se à Polícia Civil, desempenhando funções de Polícia Judiciária, enquanto a Polícia Militar faz a parte preventiva do policiamento.

A Delegacia Seccional de Branca abrange os cinco distritos policiais do município, as delegacias de polícia de outros seis municípios da região (Verde, Vermelho, Amarelo, Azul, Marrom e Cinza), além do Primeiro Distrito Policial de Verde, da Delegacia de Investigação de Entorpecentes (DISE), da Circunscrição de Trânsito (Ciretran) da região, da Delegacia de Polícia de Defesa da Mulher e da Delegacia de Polícia de Investigações e Infrações Contra o Meio Ambiente (DIMA), que entrou em funcionamento em setembro de 1994. A Delegacia Seccional de Branca está subordinada à Delegacia Regional de Prata. Esta é uma das dez delegacias regionais existentes no Estado de São Paulo, que aglutinam as delegacias de sua área. As dele-
2 O Ministério Público segue a mesma estrutura, embora ele não seja parte do Poder Judiciário. Esse órgão possui um posição institucional sui generis, não sendo diretamente subordinado a nenhum dos três poderes da União. A Constituição de 1988 fortaleceu algumas mudanças que o Ministério Público vinha implementando, ampliando o papel mais claramente voltado para a defesa dos interesses da sociedade, com mais poder para levar adiante esta função. O promotor de justiça representa o lado ativo da justiça e o juiz o seu lado passivo. $\mathrm{O}$ juiz não dá partida a um processo. Este papel cabe ao promotor de justiça. Entre eles, há auto-identificações distintas no que tange à sua função primordial. Uns falam de si mesmo como fiscais da lei e outros como os titulares da ação penal, os defensores da sociedade. A nuance na diferença é que um fiscal da lei pode identificar-se prioritariamente com o sistema legal, a ordem, o Estado, enquanto que o segundo vê-se atuando em nome da sociedade, na proteção do interesse público e social. 
3 Alguns desses profissionais exercem atividades docentes nas faculdades de Direito da região. Ministrar aulas costuma ser uma ocupação secundária que a lei permite que seja desempenhada pelos juízes e promotores. Outras atividades profissionais são vetadas a essas duas profissões. Há delegados de polícia que prestam serviços de consultoria em segurança. Em geral, os advogados não sofrem restrições legais para o exercício de outras ocupações. Há outras posições profissionais no campo jurídico que não foram detectadas na região, como é o caso dos jurisconsultos. gacias regionais se reportam ao DERIN - Departamento das Delegacias de Polícia de São Paulo e Interior, cujo responsável é o delegado-geral, chefe da Polícia Civil nomeado pelo Secretário de Segurança Pública.

Na região estudada, a estrutura organizacional da Delegacia Seccional é maior do que a da comarca de Branca, abrangendo esses seis municípios que estão sob a jurisdição de outras 4 comarcas. Portanto, a população afeta à Delegacia Seccional é de 283.461 habitantes. O número de processos que entraram em tramitação nos cartórios judiciais no ano de 1992 foi de 12.125. O número de inquéritos policiais abertos nas delegacias da Seccional de Branca, em 1993, foi de 3.510. A Delegacia Seccional conta com 29 delegados, sendo duas mulheres.

Há dois caminhos básicos para um processo ter início. Quando se trata de um processo criminal, ele começa na delegacia de polícia com a preparação do inquérito policial. Este é aberto quando há infração penal e é presidido pelo delegado de polícia. O inquérito reúne as provas colhidas durante a investigação voltadas para a apuração do crime. As delegacias têm 30 dias para concluir o inquérito e protocolá-lo junto à autoridade judicial. Se necessitarem de uma prorrogação de prazo podem solicitar outros 30 dias ao juiz. O caso só vai para o Judiciário se o delegado de polícia abrir o inquérito policial. Se o inquérito não for aberto, o caso 'morre' na delegacia. Um inquérito mal preparado, com falhas técnicas e omissões de informações pode atrasar e dificultar a tramitação do processo na justiça. A maioria dessas falhas é atribuídas ao despreparo profissional, mas há quem aponte também a omissão intencional, a corrupção, onde o delegado age desta forma para evitar a abertura ou o andamento de um processo. A delegacia de polícia tem responsabilidade nos processos vinculados à justiça criminal. Quando se trata de um processo cível, a responsabilidade sobre sua abertura é do advogado, que prepara a ação e a protocola. O cartório distribuidor a encaminha, aleatoriamente, a um dos cartórios judiciais e a ação se constitui, a partir de então, em um processo. Quando é um inquérito policial (afeto à justiça criminal) o cartório distribuidor encaminha-o para o Ministério Público. Se o promotor constatar que tem um caso, ele faz a denúncia e o inquérito se transforma em processo criminal. É esse poder de iniciar ou não a movimentação da máquina judiciária que dá o caráter ativo ao Ministério Público e o caráter passivo à Magistratura.

Além desses personagens atuando no campo da justiça, os advogados e os funcionários do Poder Judiciário completam as posições profissionais existentes em Branca ${ }^{3}$. Lá, a OAB registra cerca de 580 filiados, sendo que a estimativa é de 150 profissionais atuando como advogado em Branca. O total de funcionários dos cartórios judiciais é de 135.

Acomarca é estruturalmente organizada em 6 varas e cada uma dessas varas possui um cartório. Há dois fóruns, um criminal, com duas varas e um cível, com quatro varas. A posição mais alta da hierarquia profissional local é a do juiz responsável pela vara, que responde aos desembargadores do Tribunal de Justiça, em São Paulo. Dois cargos estão subordinados diretamente ao juiz: o 
de diretor de cartório e o de oficial de justiça. Este último está funcionalmente atrelado à vara e não ao cartório. Vinculados ao diretor do cartório estão os escreventes-chefes de setor, os escreventes e os auxiliares judiciários.

Há seis categorias de auxiliar judiciário, mas as quatro primeiras se referem aos faxineiros, às encarregadas da copa e da limpeza do prédio. As funções administrativas são afetas ao topo da escala dos auxiliares judiciários, que desempenham atividades como atendimento ao público, arquivo, autuação de processo e encaminhamento de cargas para advogados, promotores, juízes, contadores e escreventes.

O escrevente tem como responsabilidade 'tocar o processo', fazer mandato, preparar ofícios. O escrevente-chefe distribui as atividades, encarrega-se da parte de provimentos, do que é publicado no Diário Oficial, e da organização das pastas individuais com o histórico dos funcionários. $\mathrm{O}$ diretor do cartório mantém contato com os chefes, estrutura o organograma do cartório, distribui as funções, supervisiona o trabalho e é o responsável pela conexão entre o juiz e o cartório. Junto com o juiz, decide promoções e a alocação de funcionários em cargos de confiança (alguns cargos de chefia e a posição de oficial-maior, que é o substituto do diretor).

O oficial de justiça cumpre mandatos que partem diretamente do juiz. Ele faz a intimação de uma testemunha para comparecer a uma audiência, dá ciência a um réu, a um devedor executado, cumpre ordens de despejo e penhora de bens. O oficial de justiça só se reporta ao juiz e é a ele subordinado. O ingresso no Poder Judiciário se dá via concurso, tanto para auxiliar judiciário e escrevente quanto para oficial de justiça e magistrado. O mesmo acontece nas posições do Ministério Público e das delegacias de polícia. Entre os recém-formados há a imagem de que o concurso para magistrado é o mais difícil, com exigências de conteúdo superiores aos do Ministério Público. Os exames para ingresso nessas carreiras reproduzem a hierarquia profissional, na forma como se percebe a valorização social dessas profissões.

A estrutura organizacional da comarca Branca conta com 8 diretores de serviços, 23 escreventes-chefes e oficiais maiores, 56 escreventes, 14 auxiliares de justiça, além de 2 fiéis e um menor colaborador. O número de oficiais de justiça é de 31 .

Quanto aos advogados que atuam em Branca, mais de $80 \%$ o fazem nas áreas cível e trabalhista. As ações mais frequientes são as de despejo e cobrança ou aquelas vinculadas à família, como separação judicial, divórcio e pensão alimentícia. A OAB de Branca estima que $30 \%$ de seus filiados sejam do sexo feminino.

\section{A morfologia dos profissionais entrevistados: a socialização no mundo do direito}

O que dá a estes grupos profissionais uma lógica de pertencer ao mesmo universo é que, além do fato de lidarem com a questão da justiça, 
vivem cotidianamente uma intensa socialização no mundo do Direito, com uma linguagem própria, um jeito de agir e até uma aparência semelhante no vestir, dada predominantemente pelo ambiente do fórum. Embora este padrão se modifique nas delegacias, ele é um patamar distintivo para o delegado de polícia, em relação às demais posições na hierarquia interna da polícia civil. Os delegados usam paletó e gravata e são bacharéis em Direito tal como os advogados, os juízes e os promotores, tendo partilhado uma formação universitária comum a deles, que atribui características altruístas à justiça e valoriza corporativamente os profissionais que lidam com tais questões.

Por outro lado, apesar dos funcionários de cartório não precisarem ter como pré-requisito obrigatório o diploma de Direito, o mais comum é encontrar entre eles pessoas já formadas ou cursando esta faculdade. Esses funcionários judiciais vivem intensamente a socialização no fórum, local onde trabalham e reelaboram com mais ênfase o padrão acima de conduta e de valores profissionais.

Embora o grau de exposição a esta lógica e a intensidade do processo de socialização possam ser distintos na trajetória de vida dos informantes, cada profissão que atua neste universo apresenta semelhanças internas que permitem enfocá-las enquanto grupos ocupacionais. Observamos inclusive como o processo de recrutamento tende a priorizar a homogeneização de cada um desses grupos. Analisaremos, portanto, as semelhanças e as diferenças tendo como unidade básica de referência as ocupações mencionadas acima.

\section{Os juizes}

Todos os juízes entrevistados são homens brancos. A maioria deles procede dos estratos sociais inferiores, sendo originários de famílias com baixo grau de escolaridade. Dos seis entrevistados, dois eram filhos de trabalhadores rurais, um o pai era contínuo no Tribunal de Justiça, um era metalúrgico, outro era contador e apenas um era filho de advogado. A ascensão social é o padrão na carreira de juiz da comarca Branca, revelando-se ainda mais intensa do que o processo de mobilidade social ascendente detectada no corpo da Magistratura brasileira como um todo.

A distribuição da origem social dos juízes de Branca diferencia-se daquela observada na pesquisa por amostragem realizada em cinco estados brasileiros, em 1993, pelo Idesp (cf. Sadek, 1994). Nessa amostra obteve-se a seguinte distribuição para a profissão paterna: $34 \%$ procedentes dos segmentos médio-baixo e baixo da estrutura social, com ocupações de baixa qualificação no trabalho não-manual (contínuo, auxiliar de escritório), ocupações manuais (ferroviário, operário) e trabalhadores rurais; $32 \%$ provenientes do segmento médio-médio, com ocupações burocráticas e de escritório ou pequenos comerciantes; e $34 \%$ nos segmentos médio-alto e alto, sendo que $20 \%$ destes estavam ligados às atividades jurídicas. Este survey identificou uma participação feminina da ordem de $11 \%$ na carreira de juíza.

Os quatro juízes de origem social mais baixa eram filhos de mulhe- 
BONELLI, Maria da Gloria. A competição profissional no mundo do Direito. Tempo Social; Rev. Sociol. USP, S. Paulo, 10(1): 185-214, maio de 1998.

res cuja atividade estava concentrada no lar. Eram donas de casa. Já os dois restantes eram filhos de professoras.

A Faculdade de Direito freqüentada pela maioria deles é privada. Embora não tenhamos informação para um deles, encontramos um juiz formado no Mackenzie, dois na Unaerp, em Ribeirão Preto, e um na Faculdade Municipal de São Bernardo. Apenas um juiz cursou a USP, na capital.

Três dos entrevistados ingressaram na Magistratura bem cedo em suas carreiras profissionais (até 25 anos), dois começaram em torno dos 30 anos (29 anos e 33 anos) e apenas um tornou-se magistrado aos 43 anos. Hoje, a idade mínima para o ingresso é de 23 anos e exige-se uma experiência anterior como advogado ou promotor de dois anos. Se o candidato já é funcionário de cartório, ele é dispensado desta última exigência e pode prestar concurso assim que se graduar, caso tenha a idade necessária. A incidência de juízes que tiveram uma longa experiência profissional em cartório é muito elevada na comarca Branca. Dos seis juízes, quatro passaram toda a sua juventude trabalhando em cartórios judiciais de outras comarcas, onde ingressaram com idades entre 10 e 13 anos. A intensa socialização no ambiente e nos valores do fórum, quando jovem, favorece a procura por este tipo de carreira, e parece auxiliar a aprovação no exame de seleção. Desses quatro, dois exerceram a advocacia por mais de 10 anos antes de ingressar na carreira de magistrado, mas acabaram se redirecionando para ela. Dos demais juízes da comarca Branca, um exerceu a advocacia por pouco tempo e o outro foi promotor por dois anos e meio.

No momento da entrevista, em 1994, a distribuição desses magistrados por faixa etária era: um com mais de 50 anos, dois entre 40 e 49 anos e três entre 30 e 39 anos. O interior de São Paulo é a região de origem da maioria desses juízes, embora nenhum seja de Branca. Apenas um veio da capital de São Paulo e um do Rio de Janeiro.

\section{Os promotores}

Todos os seis promotores são homens, sendo que um deles poderia não ser classificado como branco, se ele assim indicasse. Dois desses promotores se recusaram a conceder entrevista, o que reduz a amostra a quatro. Mais ainda do que os juízes, os quatro promotores entrevistados fizeram mobilidade ascendente, sendo filhos de pessoas de origem social mais baixa. Dois tinham como ocupação paterna atividades do setor rural, um como trabalhador e outro como sitiante. Os pais dos dois restantes trabalharam, um como escriturário e o outro como contínuo. Diferentemente dos juízes, todos os promotores eram procedentes dos segmentos mais baixos da hierarquia social, não encontrando nenhum de origem no estrato médio-alto ou outro segmento acima deste. A ocupação materna era dona de casa.

As faculdades que todos os entrevistados cursaram eram particulares e localizavam-se fora da capital do Estado. Dois freqüentaram a Faculdade de Direito de São José do Rio Preto, um cursou a de Osasco e um fez em 
Pirassununga.

A faixa etária dos promotores entrevistados oscilava entre 32 e 47 anos. Dois estavam na faixa dos 30 e dois na faixa dos 40 anos. Apenas um deles nasceu na capital de São Paulo e um no Nordeste. Os dois restantes nasceram em municípios do interior do Estado.

A experiência profissional anterior ao ingresso no Ministério Público mostra uma aproximação e uma socialização no universo do Direito, da norma e da ordem, mas não aponta para a experiência de trabalho no fórum, como o constatado entre os juízes. Assim, um promotor começou a trabalhar aos 16 anos, num escritório de advocacia e ficou neste emprego até ingressar no MP dez anos depois. Outro, freqüentou a escola de sargentos, e foi militar até ingressar na carreira de promotor. Um terceiro, embora aprovado também para a Magistratura, optou pelo Ministério Público. Ele havia cursado a faculdade de História, mas a abandonou preferindo estudar Direito, embora o pai preferisse que ele cursasse Agronomia. Uma trajetória semelhante, de ter contato com outro curso superior antes de ingressar em Direito, também foi observada num promotor que fez uma opção mais tardia, pela carreira do MP Antes, cursara Letras e seguira a trajetória de professor. Atuava como diretor de escola ao mesmo tempo que exercia a advocacia, quando se tornou promotor.

\section{Os delegados de polícia}

Quando iniciamos o trabalho de campo a Delegacia Seccional de Branca contava com 15 delegados, mas ela recebeu um reforço de 14 novos delegados. Deste total de 29, entrevistamos 18, sendo seis recém-ingressos. Essa amostra é composta de 17 homens e uma mulher. Tal como observado entre os promotores, um deles poderia não ser classificado como branco se fizesse tal opção.

Há oito delegados na faixa etária dos 25-30 anos, 5 na faixa dos 31-40 anos e 5 com mais de 40 anos, sendo que o mais velho tinha 51 anos. A última faixa só é encontrada entre os profissionais antigos, mas as duas outras são detectadas em ambos os grupos: os que acabaram de ingressar e os que já trabalhavam antes.

A origem social desses delegados também aponta para o processo de mobilidade intergeracional ascendente, mas com um percurso de distâncias sociais menores. Nenhum dos informantes tinha seu pai trabalhando no meio rural. O ponto de partida mais baixo para a ocupação paterna é o trabalho manual urbano com alguma qualificação. Quatro delegados têm sua origem social no estrato médio-inferior, onde a ocupação do pai era a de motorista, marceneiro ou mecânico; sete no estrato médio-médio (comerciante, dono de taxi, sargento); cinco no estrato médio-superior (professor secundário, oficial de cartório, funcionário público com diploma de advogado) e dois no segmento alto (advogado e contador).

O processo de socialização nos valores do mundo da ordem, seja pela lógica do Direito, seja pela da polícia, antecede o ingresso na carreira 
BONELLI, Maria da Gloria. A competição profissional no mundo do Direito. Tempo Social; Rev. Sociol. USP, S. Paulo, 10(1): 185-214, maio de 1998.

para oito entrevistados. Estes, já no ambiente familiar conviveram com tais perspectivas, já que quatro pais exerceram atividades profissionais na Polícia Militar e na Civil e outros quatro obtiveram título de bacharel em Direito.

A maioria dos delegados entrevistados acabou intensificando esta socialização prévia com os valores vigentes neste universo mediante o ingresso nas delegacias para trabalhar como investigador ou escrivão de polícia (11 deles). Outros quatro tiveram experiências como militar ou como funcionário do fórum. Apenas cinco afirmaram não ter experiência profissional nesta área, embora um deles fosse filho de policial, tivesse um irmão delegado e uma irmã que foi investigadora de polícia. O condicionante da socialização anterior atua fortemente nesta carreira, tal como a tendência endogâmica observada no processo de recrutamento e seleção na Magistratura.

A grande maioria das mães (13 delas) dedica-se à atividade doméstica, quatro são professoras e uma foi cozinheira. A região de origem dos delegados entrevistados tem a predominância do interior de São Paulo, com destaque para aqueles nascidos nos municípios da Seccional de Branca e redondezas. Dos 14 delegados provenientes do interior, oito são desta área. Há três da capital e um da região do ABC.

As faculdades de Direito cursadas pelos delegados são todas privadas. A Faculdade de Direito de Branca é a de maior incidência na amostra, com cinco delegados tendo concluído seu curso lá. A grande maioria cursou faculdades particulares do interior do Estado ou de municípios da Grande São Paulo, excluindo a capital, onde apenas um estudou, se formando no Mackenzie.

\section{Os advogados}

Entrevistamos 16 advogados atuantes na comarca de Branca, sendo cinco mulheres. Destes, cinco estão na casa dos 30 anos, quatro estão na faixa dos 40/50 anos, quatro na faixa dos 50/60 anos e outros três com mais de 60 anos. Dois são filhos de fazendeiros (um deles também era político), um é filho de dentista, um de professor secundário, outros sete são filhos de comerciantes, um trabalha com expedição de mercadorias numa indústria, um era filho de cabeleireiro, um de sitiante, um de carroceiro e um último era filho de um trabalhador rural. A ocupação materna predominante é a de dona de casa, embora haja uma professora, uma enfermeira, uma lavadeira e uma trabalhadora rural entre as mães desses advogados.

A origem social destes informantes não permite estabelecer uma proporcionalidade para o grupo dos advogados desta comarca, já que representa uma parcela muito pequena do contingente de advogados atuantes na região. Em geral, a mobilidade social ascendente é um fator que caracteriza os profissionais do campo do Direito nesta comarca, mas no caso dos advogados parece que entre eles é mais facilmente detectado aqueles indivíduos de uma procedência social mais favorecida, oriundos dos segmentos superiores da hierarquia social. Se comparados com os juízes e os delegados da comarca de Branca, há mais profissionais advogados que são filhos de membros das elites 
locais, embora haja migração para a região e haja também ascensão social local via obtenção do diploma de advogado. Como a maioria dos entrevistados neste grupo profissional é proveniente dos segmentos médios ou altos, as possibilidades concretas de realizarem mobilidade ascendente foram menores, já que partiram de um patamar mais elevado. Como um conjunto, os juízes e os promotores de Branca percorreram distâncias sociais maiores, partindo de famílias mais desfavorecidas e alcançando o topo da hierarquia social. Já os delegados de polícia originam-se principalmente de famílias médias.

Para o exercício da advocacia, os laços sociais e as conexões locais parecem ser mais relevantes, já que é necessário se obter clientela. As atividades profissionais ligadas ao setor público podem dispensar esta característica, já que a renda mensal não provém deste tipo de vínculo. Este fator pode ter alguma relevância na explicação das diferenças nas origens sociais destes grupos profissionais.

Todos os 16 entrevistados são provenientes do interior do Estado de São Paulo, sendo oito deles da região de Branca. Quanto à Faculdade de Direito que freqüentaram, também aqui predominam os cursos particulares do interior do Estado, com destaque para a faculdade localizada no município de Branca. Um dos informantes estudou na USP, na capital.

A experiência profissional destes informantes é predominantemente no exercício da advocacia, com escritório próprio, embora o padrão do escritório e da atividade liberal seja bastante diferenciada, de acordo com o grau de profissionalização de cada um deles. Assim, entre os que estão numa situação mais favorável, há um ex-juiz da comarca de Branca, que após a aposentadoria retomou a atividade de escritório e um advogado que era presidente da $\mathrm{OAB}$ local quando concedeu entrevista. As situações profissionais que estão numa condição oposta podem ser ilustradas pelo caso de uma mulher formada há quatro anos, que, além de dar aulas de Inglês em um curso, exerce a advocacia em casa e atende no escritório de uma conhecida alguns clientes do programa oficial da Secretaria da Justiça em convênio com a OAB local, para dar assistência advocatícia à população carente da região.

Um outro padrão de difícil profissionalização na região é o dos homens que concluíram tardiamente o curso de Direito, ingressando na prática profissional depois dos 40 anos. Quando este procedimento está ligado ao acúmulo de posições no mercado de trabalho, como funcionário público e advogado, a transição entre as duas atividades parece mais segura, já que só se completa com a aposentadoria na primeira ocupação. Assim, embora a situação do escritório possa ser menos profissional, as conseqüências para o advogado são menos dramáticas. Quando esta transição é tardia, mas envolve uma redefinição profissional por perda da posição anterior, o tipo de ingresso possível neste mercado de trabalho torna-se tão adverso, que parece marcar o desenvolvimento da profissionalização para sempre, estabelecendo limites no tipo de clientela, nas causas obtidas e nos rendimentos auferidos. Esses advogados se tornam inimigos mortais dos Juizados de Pequenas Causas, que atin- 
BONELLI, Maria da Gloria. A competição profissional no mundo do Direito. Tempo Social; Rev. Sociol. USP, S. Paulo, 10(1): 185-214, maio de 1998.

ge diretamente a faixa de clientela potencial para quem eles se voltam.

Embora a profissão de advogado se distribua por um hierarquia de status profissional, que tem seu pólo dominante entre os sócios das grandes firmas de advocacia, em Branca não identificamos nenhum advogado classificado nesta posição. Outro situação que também não identificamos na regiãoé a dos advogados assalariados por empresas. O padrão local é o da terceirização destes serviços. A polarização da condição do exercício profissional se dá sob o rótulo da atividade liberal. Todos os entrevistados se definem como advogados atuando em escritório, mas a estratificação dentro desta denominação é muito grande e gera, além das disputas comuns por clientes, conflitos mais substantivos motivados pela identificação de uma desigualdade de oportunidades, de favorecimentos, de panelinhas e outras tensões decorrentes das competições provenientes da segmentação profissional.

Embora haja uma barreira dificilmente ultrapassada por aqueles que se profissionalizaram tardiamente, quando a trajetória no campo se inicia mais cedo, as limitações parecem menos segmentadas. Ou seja, é possível alguma ascensão e mudança na situação profissional conforme a carreira do jovem advogado vai se desenvolvendo. Assim, são principalmente os informantes mais jovens, que estão construindo sua profissionalização, que recorrem aos convênios entre a OAB e a Secretaria de Justiça para obter clientes, adquirir experiência e algum rendimento. Esta prática pode ser abandonada depois que a carreira do advogado se consolida um pouco mais na região.

O tamanho do escritório, a quantidade de advogados atuando, o perfil da clientela, o tipo de causa e a área de especialização dão a dimensão da estratificação dentro da carreira. O exercício liberal esconde discrepâncias muito grandes nas condições concretas de trabalho, mas, apesar de os jovens estarem em uma situação bem mais difícil do que os profissionais mais maduros, tal condição pode ser modificada com a consolidação de sua profissionalização. Os advogados que começaram tardiamente encontram dificuldades que se perpetuam mais para eles do que para os que ingressaram no campo numa faixa etária considerada padrão.

\section{Os funcionários judiciais}

Entrevistamos sete funcionários, sendo dois auxiliares judiciários, um escrevente-chefe, um escrevente, um diretor de cartório e dois oficiais de justiça. Como no caso dos advogados, a amostra não tem objetivo de representação proporcional, tendo sido escolhida para ilustrar as atividades desempenhadas no cartório e na vara. Dos entrevistados, duas informantes são do sexo feminino.

Apenas um deles não cursou Direito. Era formado em Ciências Sociais, pela Unesp e havia sido professor de OSPB e de Moral e Cívica, entre 1973 e 1979, na rede particular e depois na rede estadual de ensino de um município perto de Branca, antes de ser chamado para ocupar a função de oficial de justiça. Os demais entrevistados cursaram ou estavam cursando a 
Faculdade de Direito de Branca.

Há uma predominância de cinco entrevistados na casa dos 25 anos, e dois entre 35 e 45 anos de idade. As perspectivas profissionais para estas duas faixas etárias são distintas. Em geral, os mais moços pensam em realizar concursos para outras carreiras, como a Magistratura e o Ministério Público, enquanto os mais velhos pretendem seguir no fórum. A carreira mais valorizada é a de juiz, seguida pela de promotor e de procurador.

A origem social dos informantes é bem típica da classe média, com a predominância de vínculos com o serviço público ou com o mundo do Direito, seja por parte do pai ou da mãe. Assim, quando o pai era de origem social mais baixa, a mãe era funcionária pública ou professora. Este é o caso dos dois informantes mais velhos. Um deles era filho de um barbeiro e o outro de um alfaiate. Na geração mais jovem, os pais tinham ocupações como as de funcionário público, advogado, corretor, viajante e professor. Apenas duas mães eram donas de casa. Outras duas eram funcionárias públicas, sendo uma formada em Direito e trabalhando em cartório e três outras eram professoras.

Alguns deles são de Branca ou de cidades da região. Embora haja também mobilidade geográfica na amostra entrevistada, ela é menor do que a observada entre juízes e promotores e foi toda feita dentro do próprio Estado de São Paulo, como é o caso da amostra de advogados.

O ingresso no fórum se deu através de concurso para escrevente ou auxiliar judiciário. Os que tinham cargos de chefia obtiveram essas promoções internamente. Elas são vinculadas ao juiz da vara, que escolhe seus critérios de seleção. Assim, alguns juízes podem optar pela promoção por antigüidade, outros por mérito, por confiança, por uma composição destas qualidades. Como os cargos de chefia são de confiança, os escreventes podem ser substituídos por outros, mas as carreiras administrativas têm um prosseguimento, já que são desempenhadas na estrutura do judiciário, um ambiente onde o juiz tem a garantia da vitaliciedade e o funcionário é um servidor público.

\section{A competição interprofissional}

Ao examinarmos estas profissões atuando em interação no mundo da justiça observamos como a competição interprofissional se manifesta condicionada pelo lugar que o profissional ocupa neste contexto. É esta interdependência das posições profissionais que estrutura a disputa por enfoques, perspectivas, privilégios, monopólios sobre objetos, campo de atuação e poder de decisão. O conflito é decorrente da existência objetiva desses diferentes lugares no sistema das profissões e não se restringe a concepções de âmbito individual. Embora condicionados, os conflitos profissionais impulsionam mudanças e dão a dinâmica do sistema das profissões. O lugar ocupado neste campo condiciona as competições profissionais e fornece também os recursos para fomentar as mudanças demandadas pelos profissionais nas situações de conflito. Este elo complexo entre condicionar e impulsionar 
BONELLI, Maria da Gloria. A competição profissional no mundo do Direito. Tempo Social; Rev. Sociol. USP, S. Paulo, 10(1): 185-214, maio de 1998.

essas relações se manifesta no âmbito das mudanças em profissionais que focalizavam determinada questão por um lado do espectro de opinião, e passam a aderir a uma nova forma de ver tal questão, tanto em decorrência do novo lugar ocupado no sistema profissional quanto da antecipação da oportunidade de mobilidade, favorecendo a reconstrução da identidade profissional e da socialização neste novo contexto de trabalho. Assim, a opinião de um juiz que passa a ser advogado ou de um delegado que vira promotor público sofre redefinições em função desta nova posição de onde passa a interagir no mundo da justiça, mas sua experiência anterior também o acompanha nas interações que estabelece na nova posição colaborando para modificá-la.

Os tipos de conflitos observados nesta pesquisa apontam para a existência de maior tensão entre aqueles que estão em posições mais próximas, reforçando a noção de que é a proximidade nos lugares ocupados no sistema das profissões que aumenta a disputa entre eles. É possível se detectar a distância entre as posições profissionais, em função da forma mais amena, mais cordial ou mais externa com que os entrevistados se referem às profissões que atuam no mundo do Direito. Esta distância é detectada principalmente na hierarquia ocupacional. O contato entre auxiliares judiciais e juízes é espacialmente próximo, mas é socialmente distante. As questões que provocam a manifestação de opiniões mais veementes e conflituosas são aquelas cuja proximidade profissional as coloca em disputa, seja jurisdicionalmente, seja negando-lhe a aceitação desejada através da contestação contínua.

Os casos de competição interprofissional identificados com mais freqüência na amostra entrevistada tem uma direcionalidade na hierarquia das profissões que reproduz a da estrutura social: são os imediatamente inferiores, seja em poder ou em prestígio social, que mais colocam em questão as posições dos que estão próximos, mas num patamar acima nesta escala de força profissional e institucional. Assim, a tensão maior da Magistratura está voltada para o Poder Legislativo, que cria as leis a serem aplicadas pelo Poder Judiciário. Na divisão de poder entre o Executivo, o Legislativo e o Judiciário, este último é o que obtém a menor cota.

Os promotores se tensionam prioritariamente com os juízes, comentando com certa ironia a característica passiva deste poder. Nesta linha, se juntam os advogados, acrescentando a crítica que procura acentuar o aspecto de funcionário público acomodado e moroso às carreiras do Poder Judiciário. Os delegados de polícia manifestam sua ‘irritação’ com os membros do Ministério Público e com as conquistas mais recentes dessa corporação, que aumentam inclusive o poder dos promotores sobre os delegados. Os funcionários de cartório concentram sua artilharia contra os advogados, caracterizando alguns como desconhecedores dos trâmites legais. Em geral, estes funcionários são bacharéis em Direito.

Exemplos da competição interprofissional com esta direcionalidade, dos imediatamente abaixo para os que estão logo acima, são reproduzidas a seguir. 


\section{Depoimentos de magistrados referindo-se ao Poder Legislativo:}

Acredito que muitos processos têm uma tramitação muito morosa, que é por força da própria legislação que é ultrapassada. Quem faz a lei é o deputado e o senador. Nós trabalhamos com o instrumental legal que temos à disposição...

É discutivel que um deputado que possa estar com processo de cassação esteja fazendo a fiscalização do Judiciário. A questão é saber qual legitimidade, qual moral teria essa pessoa... Então, embora eu não seja contra esse controle (controle externo do Poder Judiciário), eu sou contra a forma que está se pretendendo criá-lo, talvez até como instrumento de pressão política.

Depoimentos de promotores públicos a respeito da Magistratura:

Eu prestei concurso para o Ministério Público e a Magistratura e fui aprovado nos dois... Fiz opção pelo Ministério Público por diversos fatores: em $1^{\circ}$ lugar, porque o MP não tem funcionários subalternos. O promotor é aquele que exerce sua atividade sozinho. Todo o trabalho que tem que ser realizado é por ele efetuado e por mais ninguém. Então, não existe aquela preocupação de policiar o desempenho dos funcionários; em $2^{\circ}$ lugar, porque o promotor é um fiscal da lei, ele não é um órgão inerte. Ele tem sempre que estar efetuando atividades para que o juiz possa julgar; em $3^{\circ}$ lugar, entre promotor e juiz não existe nenhuma diferenciação nos vencimentos, nas garantias, nas carreiras e o promotor tem um amplo campo de atividade. Daí, então, ter me interessado pela carreira no Ministério Público. E também tem mais um porém: eu gosto muito de atuar no Tribunal do Júri e como juiz eu não teria essa opção, uma vez que o juiz tão somente preside os trabalhos. Daí minha escolha pelo Ministério Público.

Entre promotores e juizes há uma recíproca fiscalização. Toda conduta que eu faço vai para apreciação do Judiciário. Passa pelo crivo do juiz, que se discordar, achar que o crime era de vulto relativamente grave e não deveria conceder remissão, ele deve fazer as razões dele e remeter ao procuradorgeral, que funciona como o chefe do Ministério Público. Se ele achar que o juiz tem razão, ele pode designar outro promotor para tomar aquela providência que o juiz achava que eu devia ter tomado. A mesma coisa acontece com as decisões judiciais. Eu tomo ciência e se não concordar com a medida que o juiz adotou, eu recorro ao tribunal, que funciona como o órgão superior ao juiz de primeiro grau, ele pode reformar aquela decisão dele e aplicar a medida que eu postulei e o juiz não aplicou. Então, há realmente, um sistema de freios e contrapesos. Eu diria que existe uma fiscalização recíproca entre ambos.

\section{Depoimentos de advogados sobre a Magistratura:}

Eu entendo que o controle externo da Magistratura é importante... Quando a Ordem defende este controle, eles não estão simplesmente entendendo que a sociedade como um todo deve participar do conjunto de medidas que regem o Judiciário com maior transparência... A sociedade tem que tomar conhecimento. Afinal de contas, é o Estado que paga, é a sociedade que paga. Ela tem que saber como ela está pagando e porque... O controle externo seria por uma maior tramitação da justiça, melhor funcionamento dos cartórios e questão de prazo.

O juiz, geralmente, o magistrado, ele fica bitolado. Ele não tem as janelas abertas para a vida, ele fica bitolado dentro da lei e dentro da jurisprudência. Ele fica como um autômato diante dessas circunstâncias da jurisprudência e da lei, da aplicação da lei e da jurisprudência do tribunal, que valem mais do que as próprias leis objetivas: penal, processual, cível, comercial, todos os ramos da advocacia. São intermináveis. 
BONELLI, Maria da Gloria. A competição profissional no mundo do Direito. Tempo Social; Rev. Sociol. USP, S. Paulo, 10(1): 185-214, maio de 1998.

Depoimentos de delegados de polícia sobre os promotores públicos:

Os delegados não são, assim, um grupo tão unido. Tem a sua união, mas é uma união um tanto quanto frágil. Tanto que as reivindicações da categoria raramente são aceitas e cada ano que passa a carreira está perdendo mais apoio e mais prestígio e mais força de trabalho, tendo em vista justamente a falta de união. Nós podemos traçar um parâmetro com o MP, por exemplo, os delegados de polícia e os promotores. Você retornando 10, 15 anos atrás e comparando a força de um delegado de polícia com a força de um promotor público, não existia termo de comparação. O delegado era muito mais forte, tinha mais força, muito mais poder. Era muito mais atuante do que um promotor público, que sempre ficava ali, à margem. Mas a união do MP é muito poderosa. Eles são uma classe muito unida, tanto que hoje se equiparam financeiramente aos juízes e passaram a léguas de distância os delegados de polícia em termos de poder, de força, de prestígio.

Existem grupos radicais entre promotores e até entre juízes, no sentido de adquirir a subordinação da Polícia Judiciária a eles. Mas desde o início do Código do Processo Penal que existe o inquérito policial e ele é presidido pelo delegado, que é bacharel em Direito, igual ao promotor e ao juiz. Então, não tem que existir vinculação hierárquica, nem administrativa, nem judiciária. Eu acho que tem que haver uma conjugação entre as três atividades e o delegado ser reconhecido como realmente é: um bacharel em Direito, igual ao juiz e igual ao promotor. A faculdade que nós fazemos é igual à faculdade que eles fazem. Não existe bacharel de segunda ou primeira categoria, nem sangue azul ou sangue verde; todos são iguais. Existem grupos radicais entre juízes e promotores que entendem que a polícia deve ser subordinada a eles...

Depoimento de funcionários de cartório sobre advogados e promotores públicos:

Tem advogado, às vezes, recém-formado que é difícil a gente trabalhar. Às vezes, vem fazer pergunta para o escrevente, ver como que funciona um processo... Então, isso tem uma certa influência. Também deveria ser mais rígido o controle da seleção... É o advogado que tem que saber como funciona um processo e não o escrevente. Então, isso dificulta a gente...

Quem manda, quem determina, quem dá as ordens no cartório é o juiz de Direito. Quer dizer, não é o promotor. O promotor vai requerer por escrito. Se tiver que tomar alguma medida, é o juiz. É isso que acontece via de regra. O promotor não manda. Quem determina é o juiz corregedor. $O$ promotor pode requerer alguma coisa, para que o juiz tome essa medida. Aí, sim, se o juiz entender que a medida deve ser tomada, ela vai ser feita. Mas, diretamente, nós não estamos ligados ao promotor.

Se há uma competição interprofissional partindo daqueles que estão em posições próximas, mas inferiores, que é alimentada pelos valores dominantes na estrutura social brasileira, há a perspectiva inversa, embora ela seja registrada em menor grau. A reação daqueles que estão nas posições superiores se manifesta quando seus competidores conseguem representar ameaças, dada alguma vulnerabilidade, algum ponto sensível que evidencia a fragilidade da posição superior, em relação ao competidor. Desta forma, aquela profissão que pretende conquistar mais força corporativa para a sua atividade ajuda a difundir uma imagem pública negativa dos que ocupam a posição mais cobiçada. A competição interprofissional se proces- 
sa mais intensamente nos dois sentidos quando há possibilidades concretas de ameaças. Nestes casos, ela é observada em todas as profissões envolvidas na competição, tanto de baixo para cima quanto de cima para baixo na hierarquia profissional. $\mathrm{O}$ que a caracteriza e dá origem é a proximidade das posições ocupadas, e o que a intensifica é a possibilidade de conquistar novas áreas de domínio profissional.

Assim, ela pode ser observada nos depoimentos dos entrevistados, em situação inversa da verificada acima, partindo agora dos que estão em posições superiores referindo-se aos que, embora estejam ocupando posições inferiores, estão muito próximos ou estão em situação cujas questões que são objeto de disputa ainda não se transformaram em conquistas monopolizadas por nenhum dos competidores.

Entre os juízes e os promotores, observa-se uma competição maior partindo destes últimos para os primeiros. Uma parte dos juízes entrevistados sequer identifica a pressão e a ameaça vinda dos promotores. Seus olhos estão principalmente voltados para o problema com o Legislativo, para a discussão sobre controle externo do Poder Judiciário e as acusações de morosidade. Apesar disto, registramos intensas reações às ameaças que a nova posição do Ministério Público pode representar, colocando para os juízes a necessidade de reforçar a distinção e a superioridade de sua função.

Situação semelhante pode ser observada na reação dos magistrados às visões dos advogados sobre o Poder Judiciário que, recentemente, enfrentou o tensionamento da competição interprofissional na questão do controle externo do Judiciário e da obrigatoriedade ou não da presença de advogados nos processos encaminhados aos Juizados Especiais de Pequenas Causas.

Depoimentos de juízes sobre promotores:

Eu não vou entrar a fundo naquilo que eu acho pessoalmente porque é até deselegante falar da carreira do outro. Acho que o MP, ter uma estrutura, uma reforma, alguma outra situação que dê outro caminho para o MP Não só ficar aí, além de propor a ação penal, ter uma atividade mais direta junto ao processo em si. Para o MP ter uma ação mais direta nos processos da polícia, ser até mais atrelado à polícia no aspecto penal. Não ficar simplesmente aguardando o que o delegado faz, para depois dar a seqüencia. O MP tem que participar mais direto das investigações, atingir mais o investigado (...). Agora, no Brasil, o MP fica esperando, embora podendo pedir diligências, fica esperando, esperando acontecer...

O Ministério Público, na minha opinião, é um poder que atrapalha. Ele não faz nada, atrapalha. Houve um tempo que não existia MP Os advogados eram nomeados pelos juizes. Isso nos anos 20, 30, e ofereciam denúncias nas versões penais e o processo funcionava tão bem ou melhor que hoje. De forma que minha opinião sobre o MP não é muito interessante... Mas o que eu questiono em relação ao MP é a finalidade da instituição. Agora, evidentemente que existem homens de bem e valor no MP. O que eu não concordo é com a instituição em si, da forma que ela está sendo levada e conduzida hoje, como também existe o Ibsen Pinheiro, que é promotor público. Ele ganhou um apartamento onde ele mora e não sabe de onde veio... Eles querem sob todos os aspectos se transformar no $4^{o}$ poder. Eles querem chegar ao lugar do juiz, sem serem juízes e isso é ruim para o povo. O que o 
BONELLI, Maria da Gloria. A competição profissional no mundo do Direito. Tempo Social; Rev. Sociol. USP, S. Paulo, 10(1): 185-214, maio de 1998.

povo precisaria, no meu modo de ver, seria um MP que fosse atuante dentro de sua função específica, que era a proteção do interesse coletivo.

Depoimento de um magistrado sobre os advogados:

$O$ advogado hoje, infelizmente, eu acho que, como em todas as carreiras, o nível caiu muito, o nível do ensino caiu muito. Então, não é uma questão de péssimos advogados. Eu acho que existem péssimos médicos, dentistas, enfim, acho que toda profissão, toda carreira hoje, não sei se as pessoas chegam muito fácil ou se proliferaram as faculdades. Isso faz com que aumente o número de profissionais em cada área, então há uma perda da preparação. Eu acho, como em todas as carreiras, há um decréscimo da formação profissional. Infelizmente nós temos visto trabalhos ruins porque os novos não estão bem preparados. Os advogados antigos, a gente percebe que eles se formavam com outro conteúdo, com outro preparo. Hoje não. $O$ advogado se forma, pensa que é advogado, vai advogar e o trabalho dele eu acho que é um trabalho muito difícil de executar. Às vezes parece fácil na prática, que ele se formando e tendo uma máquina de escrever ele pode peticionar, mas o trabalho que o advogado faz fica escrito, e qualquer um pode vir e examinar as falhas profissionais... Se o advogado move uma ação ruim, fica escrito. Ninguém vai conseguir apurar que o médico errou na sala de cirurgia, ao passo que outro profissional da mesma área vai verificar que o advogado errou naquele processo, entrou com a ação errada... A advocacia é uma profissão difícil de se exercer porque aquilo que a gente escreve fica arquivado, e amanha qualquer um pode chegar e ver o erro, a imbecilidade do advogado em questão. Então, é muito difícil no dia a dia.

Depoimentos de promotores públicos sobre os delegados de polícia:

A polícia, eu acho que ela é um pouco lenta, ela tem retardado um pouco as investigações, mas decorrente do próprio excesso de trabalho. Se lá existe lentidão, aqui já existe uma pressa bem maior.

Na polícia existe corrupção, principalmente nos grandes centros. É preciso haver um controle muito grande para evitar a corrupção. Na Magistratura a corrupção é coisa raríssima, então, na polícia é mais comum, infelizmente. O grande problema da polícia é esse daí: corrupção. Mas, não generalizando, dizendo que todos são corruptos, mas é preciso um controle bem grande, porque eles estão trabalhando numa atividade que é muito propícia.

\section{O conflito com o poder legislativo}

Esta questão unifica os profissionais do campo da justiça, que se aglutinam em torno do Judiciário, para manifestar seu descontentamento com o Legislativo, principalmente no que se refere ao estado da legislação e das leis processuais, consideradas ultrapassadas e inadequadas para o andamento eficaz do sistema judiciário. Promotores, advogados, delegados de polícia, funcionários de cartório, todos se juntam aos magistrados identificando as acusações de morosidade da justiça como responsabilidade do Poder Legislativo e dos instrumentos legais à disposição. Portanto, se há pontos de tensão entre as profissões vinculadas ao mundo do Direito, há pontos de união, de interesses comuns, que configuram este universo como um sistema profissional específico, como um campo próprio que chamamos aqui de mundo da justiça. Os conflitos com o Legislativo dão a dimensão de que os profissionais do Direito vin- 
culados ao Judiciário constituem um campo diferenciado dos demais.

Opiniões dos membros do Ministério Público sobre o Legislativo:

Uma parte dessa crise vem das leis processuais, que permitem muitas vezes recursos intermináveis. Então, as leis tinham que se aperfeiçoar no sentido que estamos presenciando agora com a criação dos Juizados de Pequenas Causas.

No tocante à morosidade da justiça, isso é um problema legal, não é problema praticamente da justiça, mas um problema de lei, onde existem prazos estipulados que devem ser observados. Além, obviamente, da necessidade do advogado, por exemplo, em obediência ao princípio do contraditório. Aí existe interesse do advogado em procrastinar o andamento do feito. É isto que traz lentidão...

Opiniões de um delegado de polícia a respeito da ação do Legislativo:

No aspecto criminal, eu acho que se deveria atacar principalmente o sistema penitenciário, porque nós estamos atacando, o legislador está atacando o processo ao contrário. Em vez de procurar retirar da sociedade o delinqüente e procurar recuperá-lo, eles estão investindo nesta parte e afrouxam as leis. Então, dá abertura dentro das leis penais para que o juiz e até o promotor pleiteiem a liberdade do delinqüente sem ele estar recuperado. Até por pena da pessoa, de recolhê-lo a uma cadeia pública, a uma penitenciária, a uma casa de detenção, e isso prejudica a sociedade que é obrigada a conviver com o delinqüente na rua e em alta rotatividade, porque o delinqüente pratica o crime, é preso pela polícia, vai para a cadeia, passa por um estágio lá dentro para se aperfeiçoar e é solto pela justiça, porque a própria lei permite e o indivíduo volta para a sociedade para delinqüir novamente... Então, eu acho que o sistema jurídico, os legisladores deveriam dinamizar as cadeias, as penitenciárias, aumentar o suficiente para acolher todos os delinqüentes, inclusive os menores de idade, mas no sentido de recuperálos, de educá-los, de fornecer trabalho para eles lá dentro como uma terapia ocupacional. Obrigar a cumprir a pena realmente e o sistema processual ser mais rígido, muito mais rápido. Está sendo ao contrário. Eles afrouxam é o sistema processual, que o indivíduo que é preso em flagrante hoje, amanhã ele é solto, não porque o juiz quer, não porque o promotor quer, porque o legislador fez a lei afrouxar o sistema processual.

\section{Opiniões de advogados sobre a atuação dos legisladores:}

O Poder Legislativo não legisla de acordo com o hodierno político, criminal, social. Eles, os nossos legisladores que são deputados no âmbito federal, estadual e mesmo no âmbito municipal, têm dificuldades em elaborar leis com a perfeição que nós desejamos. Não existe essa perfeição. Existem muitos tropeços e muitas dificuldades que eles encontram e não têm o anteparo necessário para que as leis sejam mais céleres e mais consentâneas com a realidade da sociedade.

Tudo gira em torno da legislação. O juiz tem que se ater à legislação, o promotor também, todos que trabalham na vida judiciária, eles têm um rito a observar e o rito é estabelecido por lei. Então, se o rito fosse simplificado seria melhor.

\section{Opiniões de funcionários judiciais sobre a legislação:}

Eu percebo que a morosidade não está, assim, nitidamente na justiça em si, mas nas leis, porque as leis concebem prazos muito longo para determinado tipo de procedimento, dentro do andamento do processo. Os juízes, naturalmente, têm que respeitar as leis, os promotores também e 
BONELLI, Maria da Gloria. A competição profissional no mundo do Direito. Tempo Social; Rev. Sociol. USP, S. Paulo, 10(1): 185-214, maio de 1998.

eles fazem isso. Então, a morosidade não é deles na verdade, é própria das leis mesmo.

As pessoas aqui fazem o que podem. Tem pessoas que reclamam do Judiciário, mas a lei emperra muita coisa... Se a lei é falha, eles têm como escapar mesmo. Um maior rigor na lei consegue amenizar um pouco a morosidade... O sistema americano é diferente. O cara é preso e em nove dias ele é julgado. Já é diferente do nosso, os nossos processos têm ritos diferentes. O nosso é assim e funciona desse jeito. Nós temos que nos enquadrar nesse sistema de andamento de processo...

As disputas entre o Poder Judiciário e o Poder Legislativo se aguçaram com a Constituição de 1988, já que este foi um momento de modificação na legislação e na distribuição de forças entre as instituições que atuam no campo da justiça no Brasil. No momento da realização da pesquisa, as tensões entre os dois poderes estavam sobrepondo-se às tensões do Judiciário com o Executivo porque se colocava a oportunidade de alteração na Constituição através de sua revisão. As possibilidades de mudanças reacenderam as disputas e a defesa dos interesses específicos entre as diversas instituições envolvidas com a questão da justiça - como a Magistratura, o Ministério Público, as Delegacias de Polícia e a OAB - e os diferentes lobbies no Legislativo.

Embora esse momento específico seja muito propício às tensões entre o Judiciário e o Legislativo, por ser uma ocasião de disputa jurisdicional, a mudança na composição ocupacional dos membros do Congresso Nacional pode ter alguma influência no aumento da tensão entre estes dois poderes. Esta hipótese, que requer investigação à parte, focaliza a diminuição no número de legisladores com formação em Direito como um fator capaz de intensificar os conflitos entre os dois poderes, mesmo sabendo-se que tais tensões se originam na esfera da política e da relação entre os poderes, questões que extrapolam a dinâmica profissional. Entretanto, uma bancada no Congresso com uma participação menor de advogados que viveram uma socialização profissional e um treinamento ideológico nos valores do mundo do Direito, partilhando sentimentos comuns típicos do processo de formação profissional, pode atuar como tensionador e como diversificador desse corpo de legisladores, que experimentaram outras vias de socialização nas suas trajetórias anteriores ao ingresso no parlamento.

A mudança na composição ocupacional dos membros da Câmara Federal é uma evidência de como este fator pode ajudar a tensionar as relações entre o Judiciário e o Legislativo, em momentos mais críticos desses embates institucionais. Na legislatura de 1967-1971, a Câmara Federal contava com uma participação de quase $50 \%$ de deputados com formação em Direito $^{4}$. Na legislatura de 1991-1995 esta participação caiu para 1/35. A diversificação profissional entre essas duas legislaturas materializa-se no total de profissões declaradas pelos deputados, tendo a primeira cerca de 30 ocupações e a segunda 45. Além disto, observa-se um aumento neste último período de deputados economistas, engenheiros e daqueles com ocupações provenientes dos estratos sociais menos privilegiados.

\footnotetext{
4 Dados extraídos de Deputados Brasileiros, $6^{\circ}$ Legislatura, 1967-1971, Biblioteca da Câmara dos Deputados.

5 Dados extraídos de Folha de S. Paulo, 18/09/94, Caderno Especial "Olho no Voto".
} 


\section{A competição intraprofissional}

O outro tipo de competição que movimenta o mundo do Direito refere-se às disputas e tensões vivenciadas pelos pares no interior da profissão a que pertencem. As distintas posições que compõem a profissão, que se apresenta estratificada em diferentes subgrupos, pode inclusive favorecer a segmentação por gênero, etnia ou geração, com grupos profissionais monopolizando critérios de seleção de novos pares, introduzindo novas discriminações e multiplicando conflitos entre seus membros. A idéia central no conceito de competição intraprofissional opõe-se à visão da profissão como um grupo coeso, com uma única identidade coletiva. Ele procura mostrar esta construção como uma perspectiva ideológica, que se propõe a fortalecer a profissão como corporação. Isto não significa que tal estratégia obtenha sucesso em anular as tensões decorrentes dos diferentes lugares existentes na hierarquia interna do campo profissional, mas ela é bem sucedida em gerar o sentimento de pertencer a uma corporação e a um grupo profissional apesar dos conflitos internos.

As associações profissionais e os demais órgãos de classe enfatizam a construção desta identidade comum, mas a estrutura profissional se encarrega de dificultar tal percepção, gerando disputas e competições intraprofissionais. Os recursos de poder profissional que estas entidades controlam reforçam a adesão a elas. Entretanto, as associações constroem sua legitimidade junto aos seus filiados através da ênfase no papel político e social que o grupo profissional desempenha, buscando reforçar os laços profissionais minados pelos conflitos internos, decorrentes das distintas posições na hierarquia da profissão.

Há, na percepção dos profissionais, a sensação que sua atividade possui maiores dificuldades de agir como um grupo unido, identificando naqueles um pouco mais distantes uma integração maior, uma ação coletiva mais eficaz, um sentimento de comunidade maior. Esta é uma característica decorrente da proximidade com que o profissional focaliza seu grupo e do distanciamento com que vê o outro. Assim, a perspectiva de sua visão é distinta num caso e noutro. Para o seu grupo de pertencimento, ele utiliza uma lente de aumento, já que o conhece por dentro. $\mathrm{O}$ grupo ao qual atribui um poder maior de organização e força é geralmente visto de fora, com menos conhecimento da situação interna, o que permite construir esta visão de maior unidade e poder. As lentes utilizadas para examinar ambas as situações têm capacidades distintas, alterando o resultado encontrado. A competição intraprofissional é detectada tanto nas profissões mais fortes quanto nas mais fracas, embora possa ter efeitos diferentes em cada uma delas.

O que garante a força profissional não se reduz a uma questão de unidade a priori como se os interesses fossem comuns por natureza ou por decreto. É necessário controlar outros fatores, como a seleção do grupo, o monopólio do exercício profissional, o controle do mercado de trabalho, a autonomia profissional, a capacidade de criar o problema que a profissão se 
BONELLI, Maria da Gloria. A competição profissional no mundo do Direito. Tempo Social; Rev. Sociol. USP, S. Paulo, 10(1): 185-214, maio de 1998.

propõe a solucionar através da produção de conhecimento abstrato, a titulação superior e as credenciais que diferenciem seu possuidores. A conjugação desses fatores mostra-se muito mais eficaz para o poder profissional do que a perspectiva de uma única identidade comum.

Vejamos como a competição profissional se manifesta em cada profissão estudada.

\section{A Magistratura}

Entre os magistrados, tal competição foi identificada de duas formas. A primeira delas reflete uma tensão entre primeira e segunda instâncias do Poder Judiciário, que se materializa nos cargos de juiz e desembargador, dois patamares da estrutura hierárquica da carreira, embora os juízes construam uma lógica para a profissão, onde eles se apresentam como independentes e sem nenhuma autoridades acima da sua, já que eles têm plena autonomia para julgar. A noção de justiça se alicerça na independência do juiz para julgar. É na primeira instância que o juiz julga um processo. A segunda instância é outro grau de jurisdição. Nela, julgam-se os recursos. O juiz deixa de judiciar nos processos e passa a julgar recursos de processos. Em todas as entrâncias da primeira instância o juiz julga processos, ouve as partes, colhe testemunhas. Na segunda instância, os tribunais rejulgam ou reavaliam a decisão do juiz através do recurso, se a parte que não está satisfeita com a decisão assim desejar. Não cabe ao tribunal fiscalizar o juiz de primeira instância. Este papel pode ser exercido pela Corregedoria Geral da Justiça e pelo Conselho Superior da Magistratura. Os juízes não possuem um chefe. Esta é uma das características da autonomia profissional, mas um desembargador tem mais prestígio social e força na corporação, representando uma etapa acima na carreira da Magistratura. Essa tensão, quando captada nas entrevistas, aparecia como uma forma dos informantes referirem-se a alguma lentidão maior no andamento dos processos na segunda instância e não na primeira instância aonde eles atuavam.

Outra forma de competição registrada nas entrevistas auxilia a construção de uma imagem pública séria, competente, dedicada ao trabalho, com vocação para a carreira de juiz. Tal identidade faz contraponto com o comportamento daqueles magistrados que mais se assemelham ao lado negativo do funcionário público, que despacha o mínimo necessário para continuar sua trajetória sem maiores problemas éticos ou de desempenho. Há alguma associação entre a trajetória profissional anterior ao ingresso na Magistratura e esta auto-imagem, mas ela não pode ser reduzida a isto. Entre os que tiveram experiência na advocacia, a demarcação com o padrão funcionário público parece mais intensa do que entre os que fizeram sua carreira anterior apenas no cartório.

O juiz funcionário é uma construção do outro. É uma forma de usar o estereótipo para se diferenciar. É uma maneira de falar de si mesmo como ativo, dedicado, trabalhador, com uma carga diária de 12 horas de serviços, 
levando processo para casa nos fins de semana. Ninguém se identifica na posição do funcionário que faz corpo mole no trabalho. Ela serve para reforçar a dedicação, a vocação, a competência, a melhor qualificação e o merecimento de tal posição profissional prestigiada.

Sou vocacionado para a Magistratura e enquanto advogado tinha o maior prazer em advogar, mas senti que era o momento de eu conseguir ser juiz... Todo juiz deveria, necessariamente, ser previamente advogado por um período de no mínimo cinco anos, com muita dedicação... O juiz, ele tem uma carga de serviço que vai muito além daquilo que seria o ideal. $O$ juiz tem que trabalhar diariamente de 12 a 14 horas. Eu estou falando de juiz que trabalha. Não estou falando de alguns que tem realmente uma exceção que não é muito ligada em trabalho, não é vocacionada e deveria estar em outro ramo, menos na Magistratura. Mas a maioria ainda é dada a trabalhar...

Os juizes que vieram de uma carreira relativamente curta como advogado, eles sabem conduzir melhor os processos, sabem decidir melhor, têm mais sensibilidade, mais vivência e, principalmente, ele sabe olhar os dois lados. Ele sabe olhar o lado da Magistratura, do poder público, mas também sabe olhar o lado do advogado, que, até por dispositivo legal, é um auxiliar da justiça. Ele não é um estranho. Essa interação entre Poder Judiciário e o advogado tem-se bem. É diferente de um juiz, por exemplo, que saiu dos quadros de funcionário do fórum, porque ele era funcionário e via, de um modo geral, o advogado como um adversário, porque para o funcionário o advogado que faz pedido de balcão, ele vê o advogado como adversário, alguém muito chato, que só enche o saco, aborrece, que só faz pedidos esdrúxulos. Enfim, quando ele entra, passa em concurso, ele continua mais ou menos com a mesma visão do advogado. Ele nunca foi advogado e se ele nunca exerceu a profissão, ele não sabe como funciona e não sabe o aperto do advogado em certas ocasiões... A minha experiência diz que, com algumas exceções, aqueles juízes que vieram dos quadros da advocacia são excelentes, são bons juízes. Aqueles outros que vieram da faculdade direto para a carreira por concurso ou vieram de cartório deixam a desejar um pouco, pelo menos no começo.

\section{As Delegacias de Polícia}

A competição intraprofissional detectada entre os delegados de polícia manifestou-se principalmente de quatro formas:

a) hierarquicamente, captada nas críticas à política de promoção. Neste caso, observamos críticas de delegados que ascenderam por tempo de serviço feitas aos que obtiveram promoção por merecimento. Há uma demarcação claramente negativa deste padrão de comportamento, associando os promovidos por mérito com a politicagem, o "puxa-saquismo", enquanto a promoção por antigüidade obtém o reconhecimento legítimo neste grupo. A promoção por mérito aparece como um fator de ressentimento entre os que não galgam tais posições. Talvez eles estejam mais concentrados no interior do que na capital.

Existem dois modelos (de ascensão na carreira): primeiro, por antigüidade, e segundo, por merecimento. Por antigüidade, abrem-se as vagas. Os mais velhos, a metade dos candidatos vão por antigüidade. Então, os mais velhos vão subindo hierarquicamente. A outra metade é composta de puxasacos, maçanetas e outros puxas mais. Estou falando a verdade, só progri- 
BONELLI, Maria da Gloria. A competição profissional no mundo do Direito. Tempo Social; Rev. Sociol. USP, S. Paulo, 10(1): 185-214, maio de 1998.

dem desta forma os puxa-sacos, maçanetas e outras coisas mais. A minha (carreira) é efetivamente trabalhada, eu não estou na ala dos puxa-sacos, isto eu garanto.

b) entre a geração formada a partir da democratização do país e aqueles treinados no momento de repressão associado aos governos militares. Os que demarcam mais esta diferença valorizam o trabalho baseado no conhecimento, no estudo das leis, em uma certa erudição, na imagem da delegacia como um lugar para ajudar a população em vez de ser temida por ela, uma instituição a ser procurada, capaz de atrair o cidadão.

Na época de repressão, os direitos individuais quase sempre são esquecidos. Isso é óbvio, né? E hoje, a formação do delegado de polícia é completamente voltada justamente para respeitar os direitos individuais. Pode observar, hoje em dia, o delegado de polícia, antes de autuar alguém em flagrante, ele toma muito cuidado antes de fazer isso aí. Antigamente não se pensava muito, certo? Então já se respeita. A Constituição indica vários direitos do cidadão, no caso que está sendo autuado, ou que está sendo acusado da prática de algum crime. Esses direitos todos são observados com presteza, sob pena de estar também incorrendo aí num abuso de autoridade, num abuso de poder, porque a própria lei hoje exige que seja assim. Não tem outro jeito. Nós não temos como trabalhar de forma diferente disso hoje. Temos que trabalhar em cima do que reza a Constituição e as leis. Já a Constituição daquela época é diferente. Hoje, a Constituição tem um rol de direitos inimagináveis... Hoje, um processo por abuso de poder ou de autoridade, com certeza, vai prejudicar a sua progressão na carreira, sem dúvida, mas não digo assim, abuso de poder ou de autoridade, mas um eventual engano, erro ou talvez abuso de um policial quando ele está em meio de uma ocorrência. Isso não é tão mal visto quanto um outro delito praticado contra o patrimônio, por exemplo, pelo funcionário público. Esse sim, prejudica sobremaneira a vida funcional... Esses delitos (contra o patrimônio, corrupção, peculato) causam muito mais rejeição, é mais difícil de aceitar.

c) entre os delegados com perfil mais operacional e os mais voltados para a atuação de rua, diferença pautada na experiência profissional anterior na delegacia, dada pelas atividades de escrivão e de investigador. De certo modo, esta forma de competição se interliga àquela das diferenças geracionais, com uma preferência pelo trabalho cartorário em detrimento do investigativo, pelo menos nesta região do interior do Estado.

O melhor para o delegado seria ter sido escrivão, porque o escrivão conhece o inquérito, conhece como proceder no cartório. $O$ investigador não, o investigador trabalha na rua, faz mais serviço de rua. Então, é mais difícil para ele aprender como se manuseia o inquérito... A imagem do delegado mudou. Mudou porque a população está muito descrente. Ela não acredita mais na polícia. Antes acreditava mais. Não sei se por imposição, não sei o porquê, mas ela acreditava mais na polícia... Os antigos tinham mais respaldo na lei, né? Hoje está muito difícil de trabalhar na polícia. Antigamente você falava: sou polícia. O cara te respeitava. Hoje dão risada e, certo? (...) A lei dificultou um pouco não, ela dificultou totalmente, porque com a criação dos direitos humanos, não que não tenha que ter direitos humanos, mas os direitos humanos teriam que ser para todos e não só para os marginais (Foi investigador por muitos anos em São Paulo. Ingressou como delegado 10 anos depois de formado em Direito. Estava no início da carreira, em Branca e esperava voltar para a capital) 
d) uma demarcação da distinção entre a atuação do delegado no interior do Estado e na capital. Procura-se construir uma relevância maior para o trabalho do interior diante da prioridade da capital sobre as cidades menores, fato que se verifica em quase todos os campos de atividade profissional.

Na capital você é um lugar comum, você é uma pessoa, você não tem um destaque, você é um a mais na multidão. Você vai, você trabalha, você faz o seu plantão, volta para a sua casa e esquece que existe plantão, delegacia, polícia... No interior é completamente diferente. No interior você já não tem uma vida privada, com tanta liberdade. Você é mais vigiado, você é localizado com maior facilidade, você precisa estar sempre atento aos problemas da comunidade. Na capital você tem mais violência e mais liberdade. No interior você tem menos violência, em compensação você tem menos liberdade. Você é mais marcado. Você é uma pessoa destacada. Você tem que saber o que fazer porque vai ter muita gente que vai estar te olhando... Agora, é claro, é muito mais fácil você subir por merecimento na capital, que existe muito mais casos de maior relevância do que no interior.. Um policial que resolve um caso envolvendo uma pessoa de maior destaque vai ter muito mais repercussão interna do que um outro delegado, que resolveu um caso de uma pessoa que não tem destaque na sociedade.

Observamos também alguma tensão entre a delegacia da mulher e as demais. A informante deixou evidente que sua atividade é vista como algo menor, no interior da profissão, se comparada com as questões que são enfrentadas pelos delegados. A discriminação da mulher afeta a atividade da própria delegacia.

A única coisa que eu costumo reclamar é sobre a maneira que a administração encara a delegacia da mulher. Isto é uma coisa que às vezes me incomoda bastante. Embora eu ache que os colegas da administração façam tudo para que a gente não se sinta assim, eu acho que há uma discriminação por parte dos próprios colegas e por parte da administração... Eu observo que algumas delegacias recebem muito mais reconhecimento, muito mais apoio. Aquela delegacia sempre tem maiores necessidades, ela é mais importante, ela precisa mais. Então, quanto ao trabalho da delegada, das funcionárias da delegada, é aquela coisa de que 'isso é uma bobagem qualquer, marido e mulher, sabe? Isso aí não dá, isso aí não tem peso social. Tanto mais a mulher vai brigar a vida toda, a mulher vai apanhar sempre do marido, sempre, desde que o mundo é mundo isto acontece, sabe?' Inclusive e porque tirou dos distritos esse tipo de problema, porque ninguém quer atender, ninguém gosta de lidar com esses problemas e porque a delegacia da mulher tem uma função muito especial. Acho que a maior atividade da delegacia da mulher é a social porque ela atende esse tipo de problema: familiar. Eu acho que a delegacia da mulher deveria ter um aparato maior, inclusive com profissionais melhor preparadas, eu diria assim: uma assistente social, uma psicóloga que pudessem atender..

\section{Os cartórios judiciais}

Observamos três padrões de competição intraprofissional entre os funcionários vinculados ao fórum:

a) da parte de funcionários antigos em relação aos novos, demarcando sua experiência, sua relevância, seu esforço e sua superioridade, enfatizando a falta de conhecimento dos que chegam; 
BONELLI, Maria da Gloria. A competição profissional no mundo do Direito. Tempo Social; Rev. Sociol. USP, S. Paulo, 10(1): 185-214, maio de 1998.

b) entre os auxiliares judiciários e os escreventes, onde os primeiros procuram reforçar sua qualificação ao desqualificar o cargo imediatamente superior e

c) entre as posições de chefia e os oficiais de justiça. A proximidade hierárquica dessas duas ocupações é que gera a possibilidade de disputa.

É justamente porque os oficiais de justiça não são subordinados aos diretores de cartório que se cria a oportunidade de uma disputa efetiva. A situação dos auxiliares judiciários em relação aos escreventes é semelhante, embora eles estejam um degrau abaixo do escrevente na estrutura de cargos dos cartórios judiciais. Este lugar de fronteira inferior aparece no discurso dos auxiliares judiciários quando procuram descaracterizar alguma competência maior nos ocupantes das posições de escrevente. A negação da diferença evidencia a hierarquia dos cargos, onde os auxiliares judiciários ocupam um patamar inferior ao dos escreventes.

A crise do Judiciário que eu acho que poderia existir seria, por exemplo, uma parte diz respeito à admissão de funcionário. Seria muito mais rápido um funcionário aprender o serviço que ele faz, que ele irá fazer no caso, se ele soubesse na prática exatamente como lidar com um tipo de processo, quais são os procedimentos que ele vai ter que seguir e não existe isso. $O$ funcionário faz uma prova de Português, conhecimentos gerais na área de Direito, Matemática e se for aprovado faz a datilografia que ele vai usar normalmente. Quando aprovado ele entra assim, sem saber nada do cartório. Ele só estudou, mas de procedimento processual não dá para ter noção. Então, seria legal que houvesse um curso, tipo 10 dias. (...) Eu estou aqui há três anos, sou auxiliar. Eu lido com processo, mas há pouco tempo tinha um escrevente que estava lá há dois anos e não sabia absolutamente nada sobre o processo. Então, até que esse escrevente se adapte, aprenda como ele deve proceder em processo, já foi muito tempo. Tomar iniciativa, pegar um processo e realmente estudar, batalhar para ver como ele funciona. Ele não vai aprender, então, isso é falta de preparo para ver se a pessoa tem aptidão para exercer aquela função que nem sempre tem. Às vezes, uma pessoa passa no concurso. Ele é ótimo, assim, por exemplo, como motorista do judiciário. Ele seria ótimo para cuidar dos serviços gerais, encanamento, essas coisas, mas não teria aptidão para mexer com processos.

A carreira de oficial de justiça é diferente de algumas outras carreiras, como por exemplo, da carreira de escrevente. A carreira de oficial de justiça não tem uma hierarquia. Não há, por exemplo, um oficial de justiçachefe, um oficial de justiça diretor, como acontece com a de escrevente. Então, o oficial de justiça é subordinado diretamente ao juiz da vara em que ele está lotado. Não há uma diferenciação de hierarquia dentro da carreira. O oficial de justiça, a grosso modo, ele é a extensão ou exteriorização daquilo que acontece, daquilo que é decidido, se infere, decorre, que se dá em audiência, decisões judiciais no fórum... Ele é a forma que o Judiciário tem de exatamente executar aquilo que foi determinado.

Ao mesmo tempo que observamos, no decorrer desta pesquisa, como a proximidade na hierarquia ocupacional é causadora de tensão e disputa, verificamos que a distância nessa pirâmide profissional gera deferência social. Assim, embora os funcionários de cartório sejam os personagens mais presentes no cotidiano da Magistratura, são eles que ocupam a posição estru- 
BONELLI, Maria da Gloria. A competição profissional no mundo do Direito. Tempo Social; Rev. Sociol. USP, S. Paulo, 10(1): 185-214, maio de 1998.

6 É possível que tal conduta seja mais acentuada em comarcas do interior e de regiões de médio e pequeno porte, do que na capital. Entretanto, observamos mesmo nos Tribunais de Alçada, na segunda instância do Poder Judiciário, uma padrão semelhante de lidar com o público externo, acentuando a distância e a autoridade da instituição sobre o cidadão. tural mais distante dos juízes, levando-se em conta seu lugar no sistema profissional. É da intensa socialização no fórum e desta posição claramente subordinada ao juiz que partem as avaliações e as opiniões de maior reverência ao prestígio e ao destaque do magistrado. A maneira como os magistrados são tratados internamente, nos cartórios, contribui para realimentar sua importância social. A formalidade do tratamento de Vossa Excelência extrapola o ambiente das audiências e se incorpora ao cotidiano do fórum com frequiência, quando há uma platéia externa. Os funcionários judiciais são decisivos nesse processo da construção da deferência ao juiz, porque procuram obter para a sua posição profissional algo deste reconhecimento do público, deste temor, deste respeito. A condição de funcionário de escalão subalterno é reelaborada, para o público externo, pela criação de uma conduta de superioridade, de poder, que o funcionário incorpora à sua imagem, para caracterizar a forma como quer ser identificado. $O$ fato de trabalhar vinculado ao terceiro poder da república brasileira acaba marcando o tratamento que destina à clientela, ao assumir para o seu cargo a condição de autoridade, de terceiro poder, junto a quem precisa da justiça. Realimentar a deferência à Magistratura tem resultados práticos imediatos na própria percepção de sua valoração social ${ }^{6}$.

Não é por acaso que há competição intraprofissional entre os juízes que vieram da advocacia e aqueles provenientes dos cartórios judiciais. A simbologia em torno da carreira é mais acentuada no segundo grupo do que no primeiro. Os funcionários passaram muitos anos de sua vida profissional construindo tal distinção para a Magistratura e acreditam nela com mais empenho do que aqueles que viveram essa socialização em menor grau.

Outro aspecto que a abordagem da competição profissional ajuda a desnudar é a de uma maior interdependência entre as profissões exercidas no âmbito do Estado e a produção de decisões políticas nesta esfera, que alteram as correlações de força no mundo profissional. Essas conexões entre os dois mundos ficam evidentes na tensão entre o Legislativo e o Judiciário no contexto analisado acima, nas recentes tensões entre o Judiciário e o Executivo no quadro político brasileiro e nas mudanças no prestígio da profissão de delegado de polícia. Assim, se há uma lógica própria ao sistema das profissões, ela não está desconectada de outras esferas de poder. Quando enfocamos a competição profissional no mercado de trabalho privado, percebemos como as mudanças tecnológicas são relevantes para alterar a condição de uma profissão neste sistema. Assim, o fortalecimento da profissão de jornalista não pode ser desvinculada dos avanços obtidos pela mídia, em termos de tecnologia e de expansão do sistema de informação. Ao analisarmos o campo da justiça, as mudanças profissionais que detectamos aparecem mais vinculadas à esfera do Estado e a da democratização da participação política. Este aspecto é o responsável pela alteração no prestígio dos delegados de polícia, pelo menos na forma como eles têm percebido a questão. Partindo de uma autopercepção onde se reconheciam num patamar superior de força profissional perante a sociedade, os delegados agora identificam sua posição como desprestigiada 
pelo poder público, ajudando a abalar sua imagem na comunidade.

A democratização acompanhada da elaboração de uma nova Constituição fortaleceu o Legislativo após um longo período autoritário. Esta mudança acabou reforçando para o próprio Judiciário a percepção de sua posição mais desfavorável na partilha dessas forças. Dos três poderes, o Judiciário é aquele que mais precisa dos símbolos de prestígio e deferência sociais, porque sua posição em relação ao Legislativo e ao Executivo é mais vulnerável do que é mostrado no discurso dos juízes enfatizando a sua independência.

\section{Conclusões}

Este trabalho procurou analisar como as profissões do mundo do Direito interagem na prática de uma comarca de médio porte, no interior do Estado de São Paulo, dando uma dimensão concreta à concepção do sistema das profissões.

Esta construção teórica identifica a competição profissional como inerente a tal mundo. Enfocamos a competição interprofissional entre juízes, promotores, delegados de polícia, advogados e funcionários de cartório na comarca selecionada.

Se a competição interprofissional deu a dimensão das disputas neste campo, a análise da forma como eles se percebem em tensão com o Legislativo, no papel que este tem de elaborador das leis a serem aplicadas pelos profissionais do Direito, dá a eles o vínculo e a interdependência constitutivos de um mundo da justiça.

A competição intraprofissional foi enfocada tomando como referência cada um desses grupos profissionais, para captar as formas como demarcam internamente suas diferenças. Observamos como os entrevistados em cada uma dessas atividades apresentavam um estereótipo da conduta profissional que desaprovavam, para se distinguir deste modelo e construir sua trajetória de uma forma afirmativa. Assim, a competição intraprofissional se manifestava no modo como os informantes desqualificavam o comportamento desses 'pares', que pareciam fictícios, já que não é comum no universo profissional alguém se auto-identificar como inativo, moroso, incompetente, corrupto, violento, apadrinhado, egoísta, antiético, sem-vergonha, inescrupuloso.

Os resultados deste trabalho de campo permitem concretizar uma análise das tensões profissionais, aguçadas no momento de sua realização pelas perspectivas de mudanças institucionais através do processo de revisão constitucional. Esses momentos abrem o campo para a disputa jurisdicional, criando a possibilidade de se alterar a correlação de força no interior desse mundo. As discussões sobre o controle externo do Poder Judiciário, sobre a introdução dos Juizados Especiais de Pequenas Causas Criminais, sobre a obrigatoriedade ou não da presença de advogado nos tribunais informais, sobre o papel do Ministério Público e as atribuições dos delegados de polícia refletem as recentes oportunidades de redefinição no mundo do Direito 
UNITERIMS:

legal profession, Brazil, judicial district. introduzidas por mudanças que extrapolam o sistema das profissões. Estudar estas profissões no Brasil requer que se repense a problemática profissional, estruturada em boa parte da bibliografia internacional sobre o papel das associações profissionais no controle e regulamentação da atividade no mercado e no pressuposto da autonomia da profissão frente ao Estado. A experiência brasileira aponta para uma relação muito mais estreita entre as profissões do direito e o Estado, contrastando com o modelo predominante nessa literatura que focaliza as profissões no mercado, fora da política e resistindo à ação estatal.

BONELLI, Maria da Gloria. Professional competition in the judicial world. Tempo Social; Rev. Sociol. USP, S. Paulo, 10(1): 185-214, may 1998.

\section{REFERÊNCIASBIBLIOGRÁFICAS}

AbeL, Richard L. (1989) American lawyers. New York, Oxford University Press.

Аввотт, Andrew. (1988) The system of professions: an essay on the division of expert labor. Chicago, The University of Chicago Press.

Adorno, Sérgio (org.). (1994) Dossiê Judiciário. Revista USP, São Paulo, março-maio . . (1988) Os aprendizes do poder. Rio de Janeiro, Paz e Terra.

Bayley, David H. (1994) Police for the future. NewYork, Oxford University Press.

BonelLI, M. Gloria. (1995) Os condicionantes da competição profissional no campo da Justiça: a morfologia da magistratura. In: SADEK, M. T. (org.). Uma introdução ao estudo do judiciário. São Paulo, Idesp/ Sumaré. 
\& Aguiar, M. M. \& Donatoni, S. (1994) A dinâmica profissional no campo da Justiça. Teoria \& Pesquisa, 9, Departamento de Ciências Sociais, UFSCar.

Bourdieu, Pierre (1989) Poder simbólico. São Paulo, Difel.

CÂmara dos Deputados (1967-1971) Deputados Brasileiros, Sexta Legislatura. Biblioteca da Câmara dos Deputados.

CARp, R. A. \& Stidham, R. (1991) The federal courts. $2^{\text {nd }}$ Edition. Washington, Congressional Quarterly Press Inc.

Carvalho, J. Murilo. (1980) A construção da ordem: a elite política imperial. Rio de Janeiro, Editora Campus.

Corsi, Jerome R. (1984) Judicial politics: an introduction. New Jersey. Prentice-Hall, Inc.

FALCÃo, Joaquim (1984) Os advogados: ensino jurídico e mercado de trabalho. Recife, Fundação Joaquim Nabuco/Massangana.

FARIA, J. E. (org.). (1989) Direito e justiça: a função social do Judiciário. São Paulo, Ática.

FLORY, Thomas (1986) El juez de paz y el jurado en el Brasil imperial, 1808/ 1871. México, Fondo de Cultura Económica.

FreIDSOn, Eliot. (1994) Professionalism reborn. Chicago, University of Chicago Press.

. (1995) An theoretical framework for the study of the professions. Conferência realizada no XIX Encontro Anual da ANPOCS. Caxambú, MG, outubro.

FuKs, Mario. (1994) Do discurso ao recurso: uma análise da proteção judicial ao meio-ambiente. Trabalho apresentado no XVIII Encontro Anual da ANPOCS. Caxambú, MG, 23-27, novembro.

Fund for Modern Courts, Inc. (1985) The sucess of women and minorities in achieving judicial office: the selection process. New York (mimeo).

Granoveter, Mark \& Tilly, Charles (1988) Inequality and labor processes. In: SMELSER, Neil J. (ed.). Handbook of Sociology. CA, Sage.

IDESP - Instituto de Estudos Econômicos, Sociais e Políticos de São Paulo. (1996) O Ministério público e a justiça no Brasil. São Paulo, Relatório de Pesquisa.

KARPIK, Lucien (1990) Technical and political knowlegde: the relationship of the lawyers and other legal professions to the market and the State. In: Torstendahl, R. \& Burrage, M. (orgs.). The formation of professions: knowledge, state and strategy. London, Sage.

LeEuwen, L. E. De Groot-Van. (1992) The equilibrium elite: composition and position of the Dutch Judiciary. International Review of Sociology. 
LEMPERT, R. \& SANDERS, J. (1986) An invitation to law and social science: desert, disputes and distribution. New York, Longman.

MingaRdi, Guaracy. (1992) Tiras, gansos e trutas: cotidiano e reforma na polícia civil. São Paulo, Scritta.

Myers, Martha. (1998) Social background and the sentencing behavior of judges. Criminology, 26(4).

Nalini, J. R. (org.) (1992) Curso de deontologia da magistratura. São Paulo, Saraiva.

Martin, Elaine. (1990) Men and women on the bench: vive la difference? Judicature, 73(4), december-january.

MONSMA, K. \& LEMPERT, R. (1994) A discriminação cultural na justiça informal. Trabalho apresentado no XVIII Encontro Anual da ANPOCS, Caxambú, MG, 23-27, novembro.

Nelson, R., Trubek, D. \& Solomon, R. (eds.). (1992) Lawyers'ideals/lawyers' practices: transformations in the American legal profession. Ithaca, Cornell University Press.

RUESCHEMEYER, Dietrich. (1986) Comparing legal professions cross-nationally: from a professions-centered to a state-centered approach. American Bar Foundation Research Journal, 3.

SADEK, M. Tereza. (1994) A crise do Judiciário vista pelos juízes. São Paulo, IDESP, Relatório de Pesquisa. (org.). (1995a) O Judiciário em debate. São Paulo, IDESP/Sumaré. (org.). (1995b) Uma introdução ao estudo do Judiciário. São Paulo, IDESP/Sumaré.

Schwartz, Stuart B. (1979) Burocracia e sociedade no Brasil colonial. São Paulo, Perspectiva.

Tilly, Chris \& Tilly, Charles (1994) Capitalist work and labor markets. In: Smelser, Neil \& Swedberg, Richard (eds.). The Handbook of Economic Sociology. Princeton, Princeton University Press/Russell Sage Foundation.

ViANNA, Luiz Werneck et alii. (1997) Corpo e alma da magistratura brasileira. Rio de Janeiro, Revan/IUPERJ. 